\title{
CYP2C8*5 Allele
}

National Cancer Institute

\section{Source}

National Cancer Institute. CYP2C8*5 Allele. NCI Thesaurus. Code C46033.

Human CYP2C8*5 allele is located in the vicinity of $10 \mathrm{q} 23.33$ and is approximately $33 \mathrm{~kb}$ in length. This allele, a variant form of the CYP2C8 wild-type allele, encodes cytochrome P450 2C8*5 protein. The CYP2C8*5 allele exhibits a clinically-relevant single nucleotide deletion (c.475delA), resulting in a coding frameshift that is predicted to cause amino acid alterations from codon 159 and an early stop codon at residue 477 . The cytochrome P450 2C8*5 protein is predicted to be enzymatically inactive since it lacks $64 \%$ of the protein coding structure, a region which includes the heme binding site and 5 out of 6 substrate recognition sites. 